ANNE-LENE SAND

Ph.d. fra Institut for Kulturvidenskaber, Syddansk Universitet

\title{
AT JAMME MED BYENS RYTMER SELVORGANISEREDE FORHANDLINGER AF TID OG RUM
}

\begin{abstract}
JAMMING WITH THE RHYTHMS OF THE CITY | Focusing on the city, this article examines the relation between the specific (body and place) and more abstract (time and space), in order to understand how people negotiate the affordances of materiality, space and time. Based on a two year anthropological multisited fieldwork, 38 people have shown and told me how they organize themselves in the city through music and dance. Focusing on the phenomenon self-organization as a special form of participation, the main argument of the article stresses that people create their own use of the city by exploring and sensing the social spaces and rhythms of the city. They improvise in their use of places that are not framed institutionally or pre-established in advance. In order to understand how people transform the city into a space for self-organization, the analytical framework of the article is the French neomarxist and urban philosopher Henri Lefebvre's rhythmanalysis. The rhythmanalysis enables us analyze the dialectical relationship between the body and the city. The first part of the article analyzes three spatial elements of the self-organized practice: How spaces become exciting, the framing of a space through sound and light and the embodied exploration of space. Secondly, the article combines observations from a jam session with Lefebvre's rhythmanalysis and specifies the main argument of the article: self-organization is a practice of improvisation and is conceptualized as a way of "jamming with urban rhythms."
\end{abstract}

KEYWORDS I city; self-organization; participation; rhythmanalysis; urban space; urban dialectics; embodied practices; unregulated space; sensory ethnography

Når man går gennem byen og observerer livet omkring sig, ser man ofte mennesker, som sidder på cafeer, går målrettet efter bestemte butikker, mødes på aftalte tidspunkter, er på arbejde og yder en bestemt service, eller mennesker som udtrykker sig musikalsk og kunstnerisk. Et kort blik på bybilledet vidner om, at der er forskellige måder at deltage og udtrykke sin deltagelse i bylivet på. Man kan derfor ikke tale om, at byen har én type byrum, da byen består af forskellige former for menneskelig handling.

Artiklens analytiske genstandsfelt er selvorganisering som deltagelsespraksis, og jeg har til hensigt at vise, hvordan mennesker improviserer i deres brug af byen. ${ }^{\mathrm{I}}$ I artiklen

I Praksis anskues ud fra en klassisk antropologisk teoriforståelse, hvis formål er at beskrive menneskers hverdagspraksis ud fra det, de gør (Jenkins, Hastrup). Perspektivet er ydermere inspireret af Michel De Certeaus (93) perspektiv på, hvordan mennesker skaber selvstændige praksisser gennem bevægelser, rituelle handlinger og symboler. 
argumenterer jeg for, at de mange måder at deltage på påvirker hinanden, og at der i dette komplekse samspil opstår deltagelsespraksisser, som ikke er indlejret i en institutionstænkning eller formaliseret social rammesætning. I artiklen betragtes byen som en referenceramme for hverdagslivet og som en aktiv medspiller, som influerer på menneskers bevidste og ubevidste måder at deltage på. Dette perspektiv på byen efterlader et spørgsmål om, hvordan mennesker forholder sig alternativt til det eksisterende byliv, og hvordan bylivet påvirker en deltagelsespraksis.

For at analysere hvordan byen transformeres til et rum for selvorganisering, tager artiklen et overvejende empirisk udgangspunkt med et teoretisk afsæt i den franske by-filosof Henri Lefebvres rytmeanalyse. Jeg anvender rytmeanalysen som en metode til at forstå, hvordan brugen af byen er sanselig, kropslig og tidslig. Rytmer er normalt noget, vi forbinder med musik, men med afsæt i Lefebvres rytmeoptik anvender jeg rytmen som metafor for menneskelige handlinger med henblik på at forstå selvorganisering som deltagelsespraksis. Indledningsvist i artiklen introducerer jeg rytmeanalysen, og gennem empiriske analyser illustrerer jeg, hvordan informanterne improviserer med byens steder, lyde, materielle genstande og kulturelle logikker ved at vende hverdagens rytmik på hovedet.

Jeg kombinerer således fænomenet selvorganisering, Lefebvres rytmeanalytiske metode og et konkret empirisk materiale, hvilket bidrager til udviklingen af begrebet en rumlig jamsession. Herigennem konkretiserer jeg selvorganisering som deltagelsesform, og begrebet er artiklens bidrag til en aktuel deltagelsesæstetik. Begrebet en rumlig jamsession bidrager som metode og analytiske tilgang til at nuancere deltagelsens æstetik i forhold til deltagelseskulturer, der beror på improvisation og ikke indskriver sig i en formaliseret kulturinstitution. Artiklen illustrerer og fremhæver samtidig betydningen af den rolle, sted og krop har, når man forskningsmæssigt vil forstå fænomener som by og deltagelse. Dette perspektiv er inspireret af den engelske socialgeograf Nigel Thrift, som sondrer mellem kropsbevidsthed og situeret kropsbevidsthed. For at forstå samspillet mellem krop og by, handler det ikke blot om at have fokus på kropsbevidsthed, hvilket Thrift betegner body -a-where-ness. Med betegnelsen body-a-where-ness fremhæver Thrift kroppens stedslige aktualisering og argumenterer for, at fænomenerne krop og by skal anskues ud fra, hvordan de gensidigt har indflydelse på hinanden (Thrift I26).

Artikel udspringer af et antropologisk flersteds feltarbejde (Marcus, Hannerz) foretaget i perioden 2OII-20I3, hvor jeg har observeret og interviewet 38 mennesker mellem I4-38 år, som kommer fra forskellige steder i Horsens og Aarhus. De bruger forskellige steder i byen og gør det gennem forskellige kropslige udtryksformer. Fælles for dem er, at de har musikken som omdrejningspunkt: De hænger ud og hører musik, danser til hardstyle musik, spiller musik i fritiden, arrangerer festivaler $\mathrm{i}$ byen, organiserer raves i nedlagte bygninger, organiserer koncerter under en bro og arrangerer fester på stranden. Artiklen handler ikke om musik, men en fællesnævner for deltagerne er, at de med reference til deres musikalske erfaringer i byen, fortæller om byen som værende en bestemt type deltagelsesrum, hvor de kan organisere deres egen musikalske praksis gennem en egen deltagelseskultur. 


\section{Rytmeanalyse}

Rytmeanalysen introducerer Lefebvre med Catherine Régulier i 1985 i "Le projet rythmanalytique" (se Lefebvre, The Production of Space, Writings on Cities 219-240, Rhythmanalysis). Lefebvre observerede byens hverdagsliv i Paris og blev i sine observationer opmærksom på forskelligartede hastigheder og bevægelser i hverdagslivet: personer der går på arbejde, krydser gaden, spiller musik, biler der accelererer, mennesker der grupperer sig og lyde og lugte. Han observerede døgnets rutiner, klokker der markerer et tidsrum, som frikvarterer i skolen, og bevægelser i byen ved fyraften. Ud fra disse observationer søgte Lefebvre med begrebet rytme at forstå, hvordan bylivet er opdelt i og sammensat af forskellige former for tidsrytmer. Lefebvre beskriver: "Everywhere there is interaction between a place, a time, and an expenditure of energy, there is rbythm" (Lefebvre, Rhythmanalysis I5, original fremhævning). ${ }^{2}$ Lefebvre giver ikke en entydig definition af, hvad en rytme er, rytmer er overalt og er en integreret del af den måde, bylivet er struktureret på. Der er både tale om, at kroppen har interne rytmer og byen har eksterne rytmer, og at rytmerne mødes og kommer til udtryk i samfundet, i byen og på gaden (Simonsen, Byens 46). Rytmer defineres som gentagelser, men gentagelserne er aldrig ens, da der altid er en forandring, der medfører en ændring og dermed skaber en ny rytme (Lefebvre and Régulier, 23I). Når det er muligt at tale om rytmer som et generelt fænomen, er det fordi, at rytmer skal forstås som en tidsudstrækning og derfor relaterer sig til forskellige aspekter ved bylivet: både det kropslige, sanselige, varighed af lyd, hverdagsrutiner, brud med regler m.v. Rytmeanalysen er således velegnet som et metodisk komparationsværktøj til at analysere forskelle og sammenhænge mellem forskellige deltagelsesformer. I artiklen anvendes rytmeanalysen som et metodisk og analytisk værktøj, der hjælper med at synliggøre informanternes konkrete selvorganiserede brug af byen og hvordan de i kontrast til det formaliserede byliv skaber egne forhandlinger af tid og rum. Rytmeanalysen er således indgangen til at forstå, hvordan informanterne skaber selvorganiserede praksisser mellem etablerede og forudsigelige by-praksisser.

I det følgende analyserer jeg tre rumlige forhold, som er fremtrædende for den selvorganiserede deltagelsespraksis og den type steder, jeg har udforsket i feltarbejdet: I) Når brugen af byen gøres spandende, 2) At gøre by gennem lyd og lys og 3) At udforske byens rytmer og arkitektur.

\section{Første rumlighed: Når brugen af byen gøres spandende}

Nogle deltagelsesrum i byen er stramt struktureret og karakteriseres ved at have en funktionslogik, som rammesætter praksis og i mindre grad er til diskussion (Sommer, Bernstein). I stramt organiserede rum er uforudsigelige handlinger i

2 "Hvor end der er en interaktion mellem et sted, en tid og et forbrug af energi, er der rytme." (Egen oversættelse). 
mindre grad kendetegnende for deltagelsespraksissen. I modsætning hertil står rum, der i højere grad appellerer til alternativ brug og fri fortolkning. Denne type rum betegner jeg i min ph.d.-afhandling for matrikelløse rum (Sand 20I4). Et eksempel herpå er musik- og koncertklubber, som er etableret uden for byens eksisterende musikscene, og hvor deltagerne selv har indflydelse på indhold, form, udtryk og præmisserne for deltagelse. Når grænserne for en deltagelsespraksis kun i mindre grad er defineret, åbner det op for spontane handlinger og uforudsigelige møder mellem mennesker. Ifølge kulturgeograferne Karen A. Franck og Quentin Stevens medfører spontanitet samtidig en risiko for, at den givne praksis ændres (Franck and Stevens). De informanter, jeg har fulgt, taler ikke om risiko, men om hvordan deres by-brug er præget af uforudsigelighed, og hvordan den medvirker til, at de oplever brugen af byen som værende spændende. 3 I det følgende illustrerer jeg, hvordan den spændende rumlighed knytter sig til fænomenerne krop, autoritet og uforudsigelighed.

Et eksempel er OPP-festerne (Other Peoples Properties) i Aarhus. OPP er et engelsk rave-fænomen, som går ud på at indtage nedlagte bygninger, installere enkelte remedier som lyd og lys og invitere folk via hemmelighedsfyldte løbesedler. Følgende to fotografier er taget til en OPP-fest.

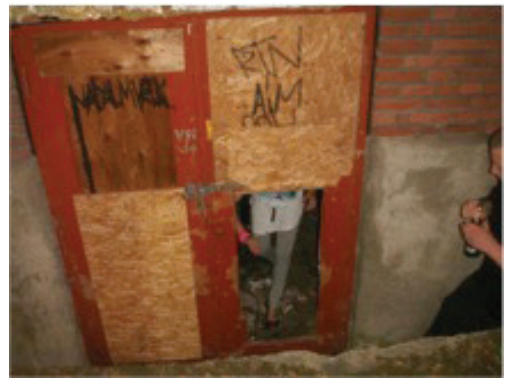

Billede I

Fotografiet viser, at indgangen til den bygning, hvor ravet skal foregå i er et smadret hul i en dør, som er barrikaderet og aflåst. For at OPP-deltagerne kan komme ind i bygningen, skal de kravle på hug igennem det smalle hul, overkroppen skal vrides på skrå, og hovedet dukkes, imens de tager et skridt for at kunne komme igennem. Selve bygningen er kun lyst op med stearinlys. Troels som er arrangør og DJ til festerne, forklarer følgende:

"Det er jo spændende at gå hernede. Det er mørkt, det er en kringlet vej, og når du først er inde i bygningen, så du hører, at der er en puls, der slår et sted, så skal du på jagt efter den. Man kan fornemme det hurtigt, for der er mange folk, som går frem og tilbage i bygningen.” (Troels, 34 år, interview i kælderen, I2.IO.20II). 
OPP er et rave, som handler om at danse til techno, men Troels har observeret, hvordan folk går "frem og tilbage i bygningen" frem for at være i det store lokale, hvor DJ'en spiller. Dette mener Troels, skal forklares med, at det er spændende at bevæge sig i bygningens gange med den afdæmpede belysning, hvor deltagerne søger efter pulsen fra bassen, som guider dem igennem bygningen.

Lefebvre placerer kroppen i forgrunden for rytmeanalysen og inddeler bl.a. rytmer i interne rytmer og eksterne rytmer. Interne rytmer er de indre rytmer i kroppen, som handler om det private, følelser, tanker og kropslige fornemmelser (Simonsen, Byens 47). Når informanterne finder det spændende at være i nedlagte bygninger, kan oplevelsen anskues som en kropslig intern rytme, der aktualiseres på det specifikke sted.

Flere af informanterne tager afstand fra det, de betegner som mainstream og refererer til strøget, diskotekslivet og byrum, der ikke er defineret entydigt af andre. Troels fortsætter:

"Tilbage til spørgsmålet om hvorfor det er fedt at komme her. Det her er en af de der små grå oaser. Nogle savner grønne oaser, det her det er så en betonoase. Den er ikke blevet ødelagt, eller hvad kan man sige, af kapital, den står stadigvæk og er rå og håbløs, og det er lige præcis det, man gerne vil ha'.” (Troels 36 år, I2.IO.20II).

Steder, der er rå og håbløse, er endnu ikke blevet ødelagt af kapitalinteresser. Disse steder karakteriserer geograf Tim Edensor som spaces of waste (Edensor), da de i et industrielt perspektiv er formåls- og nytteløse. Men det håbløse er for mine informanter fuldt af håb, nærmere betegnet potentielt for deres selvorganiserende praksis. Frodigheden, de knytter til de grå oaser, handler om en anden frodighed end den, der forbindes til grønne oaser. Frodigheden handler om steds- og deltagelsespotentialer, hvor OPP-festerne bl.a. kan få en spændende oplevelsesdimension.

Det empiriske eksempel viser, hvordan den selvorganiserede praksis opstår gennem en kontrast men også forbindelse til det præetablerede byliv, hvilket Lefebvre betegner som eksterne rytmer. Eksterne rytmer repræsenterer byen, byplanlægningen, det offentlige, samfundet og globale strømninger. Fotografiet illustrerer informanternes brud med byens lineære byliv. I modsætning hertil repræsenterer informanternes by-brug det, Lefebvre betegner som cyklisk rytmer, som via kontrasten til det præetablerede skaber et potentiale for leg, festival og selvorganisering. Citatet og fotografiet viser samspillet mellem den alternative by-deltagelse, arkitektur, lyd, lys og krop, hvor kroppens bevægelser genereres gennem sansning af bygningens gange, fabrikslokalerne, musikken m.v.

Informanterne navigerer $\mathrm{i}$ byen med konstant bevidsthed om autoriteters mulige tilstedeværelse. Ravet lukkes eksempelvis ned af politiet, og til en koncert under en bro er gruppen af venner, der organiserer koncerten, meget opmærksomme på, hvad de gør, hvis en DSB-ansat dukker op. Bevidstheden om autoriteters formelle ret til stedet forstærker den interne rytme og den konkrete oplevelse af, at det er spændende at være til stede. Herudfra understøtter kontrasterende eksterne rytmer 
den spændende stedsoplevelse. Samtidig navigerer informanterne på en hårfin balance mellem, hvad der er lovligt og ikke-lovligt. De ønsker ikke at foretage et radikalt opgør med autoriteter, da en konfrontation vil minimere deres muligheder for at bruge de grå oaser og dermed minimere det selvorganisede deltagelsesrum.

Der knytter sig også en uforudsigelighed til de cykliske tidsrytmer, som flere informanter bevidst opsøger og iscenesætter. "Uvisheden er en drivkraft i sig selv", fortæller Sebastian som arrangerer Doom-metal-koncerter under en bro i Aarhus. Kasper, som via Facebook arrangerer danseevents i en nedlagt hal i Horsens, fortæller: "Det giver et kick, når det er gået godt." Dette er et eksempel på, hvordan brugen af byen er indlejret i tidslige dimensioner. I en rytmeanalytisk optik kan begge udtalelser forstås som et udtryk for en kropslig oplevelse, der opstår som en indre kropslig rytme i mødet mellem byens tidslige og sociale uforudsigelighed.

I Lefebvres optik medvirker uforudsigeligheden til, at tidsrytmerne og de sociale relationer opererer asynkront og polyrytmisk, da rytmerne ikke er fastsatte som mange af hverdagens andre rutiner. Når informanterne fastholder den asynkrone rytme ved at iscenesætte det konfliktuerende forhold mellem organisering og uforudsigelighed, gør de uforudsigeligheden konstant, da der heri ligger et potentiale for den selvorganiserede deltagelsespraksis. Andre mennesker vil opleve de uforudsigelige rytmer som konfliktuerende, men i informanternes perspektiv skaber de en polyrytmi-komposition, hvilket vil sige, at rytmerne sameksisterer uden disharmoni (Lefebvre, Rhythmanalysis 67).

Med afsæt i ovenstående kan man sige, at informanterne ikke bevæger sig med en fast takt i byen, men at de har en kropslig åbenhed over for at håndtere uforudsigelige og spontane handlinger. I mødet mellem interne og eksterne rytmer fremstår stedsoplevelsen som spændende, uforudsigelig og som et alternativ til de eksisterende, komfortable og velordnede oplevelses- og deltagelsesmuligheder i byen.

\section{Anden rumlighed: At gøre byen gennem lyd og lys}

Lyd og lys kan betragtes som rytmer ud fra deres tidslige gentagelsesform (Lefebvre, Rhythmanalysis 2I, 64). Informanterne anvender lyd og lys som redskaber i deres selvorganiserede by-brug, og samtidig er lyd og lys med til at give informanterne en æstetisk by-oplevelse. Ifølge Lefebvre skaber ikke-sproglige rytmer og kropslige bevægelser nye deltagelsesrum i byen (The Production of Space 39). Når fænomener som lyd og lys anvendes på alternative måder, kan de anskues som rytmer, der visuelt og auditivt kontrasterer byens lineære og cykliske hverdagsliv. I det følgende giver jeg to eksempler på, hvordan især lys anvendes af nogle af de 38 personer, jeg har fulgt.

I december 2010 arrangerer Kasper på I4 år et chill-meetup over Facebook, som tiltrækker I5O personer i alderen fra I2-25 år fra hele Danmark. Et meetup er en samling af folk, der shuffler, hvilket er en dansegenre, der knytter sig til hardstyle musikken. Kasper forklarer, at et meetup kan være officielt og dermed tilknyttet 
organisationen Hardstylers United, som ud fra eksplicitte bestemmelser rammesætter selve meetup'et. Eksempelvis ved at tage entré, have dørmænd, fastsætte tidspunkter for, hvornår meetup'et skal lukke m.v. En anden form for meetup er et chill-meetup, som kan organiseres af alle, og hvor man selv definerer og organiserer betingelserne for meetup'et. I stedet for at stille højtalere op og trække strøm som ved et OPP-rave, får Kasper en kammerat med kørekort, bil og et stort anlæg til at komme. Bilen bakkes ind i hallen, og musikken spiller ud fra bagagerummet. Den nedlagte hal er, ifølge Kasper, fed, og graffitien, de smadrede ruder m.v. giver stedet en karakter, som passer godt til det chill-meetup, Kasper selv organiserer. Kasper har valgt ikke at sætte lys op, og derfor slutter meetup'et ved solnedgang. Lyden får i det empiriske eksempel karakter af at være et mobilt fænomen og et rumligt forhold, som Kasper rammesætter sin praksis med. Skaterne har førsteretten over stedet, så meetup'et skal kunne flyttes, hvis skaterne kommer og vil bruge hallen. Lyden installeres derfor som et mobilt rumligt forhold, der skræddersys til det sociale rum, som stedet er indlejret i.

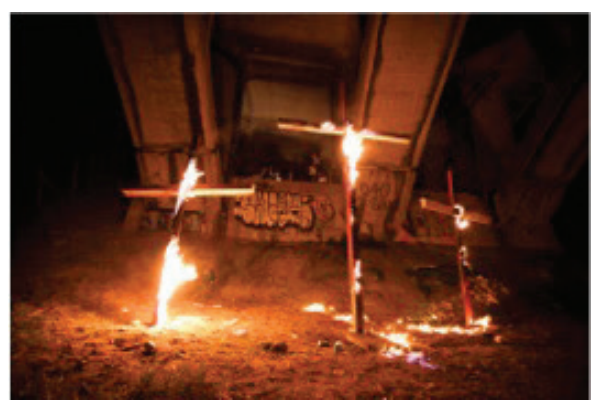

Billede 2

På fotografi nr. 2 ses "scenen" bag de oplyste kors mellem de to betonfundamenter.

I et gruppeinterview i Aarhus fortæller Daniel, Sebastian, Matias og Kristian mig, at de lejer en generator til $500 \mathrm{kr}$ til at generere strøm til koncerten under broen. Generatoren skal i behørig afstand fra "scenen", som de kalder den, for at generatorens høje brummende lyd ikke intervenerer med deres lydrum og forstyrrer lyden fra koncerten. De trækker derfor generatoren op ad skrænten ved siden af broen. Deres måde at indtage stedet og organisere koncerten på er formet ud fra deres erfaringer med musik, deres forestillinger om den lyd, de vil skabe, og ved at udforske, hvordan lyd og sted intervenerer med hinanden. Bands er inviteret til at spille, og instrumenter som trommer, guitar, cello, violin m.v. er valgt ud fra kriterier, de selv definerer:

"Musikken er først og fremmest valgt på grundlag af, at det skal være folk, som har noget interessant at vise, og især er i stand til at tage broen og inkorporere den i deres udtryk. Doom-metal er flydende og ikke så rytmisk musik, og det passer bare naturligt til det soniske miljø dernede.” (Sebastian 23 år. Opfølgende mailinterview I3.II.2OI2)”. 
I citatet er det tydeligt, hvordan musik og broens arkitektoniske forme skal skabe en helhed. Ifølge Sebastian skal musikerne kunne "tage broen”. De skal inkorporere en forbindelse mellem deres musikalske udtryk og to rumlige forhold: det soniske miljø og det, de beskriver som broens beton og monumentale udtryk. En koncert kan derfor ikke indøves på forhånd, men konstrueres i mødet med stedet under broen. Ovenstående fotografi er et eksempel på, hvordan et band inkorporerer eget visuelle udtryk ved at sætte ild til tre kors, de banker sammen under koncerten.

Samtlige informanter forholder sig aktivt til bylivet over og omkring sig. Under broen summer trafikken over kammeraterne, hvilket umiddelbart er et modstykke til den lyd, de laver under broen. Men det empiriske materiale viser, at de bruger byens lineære lyd til at afgrænse deres egen lydpraksis med. Et eksempel herpå er den måde, byens lyd kamuflerer den lyd, informanterne selv skaber under broen. Informanterne kan arrangere koncerten under broen i kraft af lyden fra trafikken. Den geografiske afstand til byen bliver mindre central for informanterne, da den arkitektoniske og lydmæssige ramme afskærmer deres lydpraksis. Informanterne skaber altså et deltagelsesrum i byen, hvor de kan organisere sig på egne præmisser.

Ovenstående viser, at de steder ("grå oaser") informanterne opsøger, ikke intentionelt er afprøvet, formålsbestemt eller kvalitetssikret som rum for lyd og lys eller en særlig type lyd og lys. Informanterne arbejder på forskellig vis med at formgive rummet og afprøve lyd i forhold til de sociale og arkitektoniske omgivelser. Samtlige informanter bruger artefakter og instrumenter, men de instrumentaliserer ikke brugen af dem. De lader derimod musikken og koncerten udvikle sig i og med stedet og byens rytmer. Dette betegner Lefebvre som en ny rytme. Den nye rytme er ikke bare en ny tidsform, da den også skaber en kropslig fornemmelse af at være til stede. Fordi rytmerne stemmer sammen i et situeret møde, kan det samme udtryk eller deltagelsesrum ikke skabes på et etableret spillested i byen. Ved at anskue måden hvorpå lyd bruges til OPP, Kaspers meetup og under broen, bliver det tydeligt, at den selvorganiserede deltagelsespraksis konstrueres som en afgrænsning og en eurytmisk og harmonisk forening af forskellige rumlige forhold: sted, arkitektur, eksterne rytmer, interne rytmer, tidspunktet, hvor stedet kan tages i brug, og det musikalske og visuelle udtryk (jf. Lefebvre, Rhythmanalysis 6).

\section{Tredje rumlighed: At udforske byens rytmer og arkitektur}

Fotografi nr. 3 er taget på Rabbit Hole Festival i 2011 i udkanten af Horsens og illustrerer to forskellige måder at indtage et sted kropsligt på. Forestiller vi os, at de to drenges måder at sidde på taget af bygningen havde fundet sted i den centralt beliggende bydel, ville andre logikker for at tage stedet i brug være indlejret i det omgivende sociale rum. Sammenstødet mellem forskellige måder at deltage i byen på kan med en rytmeanalytisk optik forstås som modrytmer (arytmi). Eksempler på disse modrytmer er følelsesmæssig respons fra forbigående som frygt for at komme til skade eller utryghed ved at se folk indtage steder på alternative måder. På dette sted er der i højere grad et legitimt rum til cykliske rytmer og selvorganiserede 
praksisser, hvilket på billedet ses, ved at arrangører og deltagere på festivalen ikke giver de to personer på taget opmærksomhed. Arrangørerne og deltagere er gennem deres kropssprog og det, at de ikke tildeler de to på taget opmærksomhed, med til at skabe et deltagelsesrum, hvor stedet kan udforskes spontant gennem individuel fortolkningsfrihed.

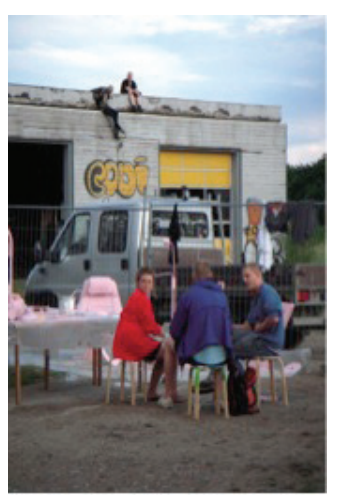

Billede 3

Et andet eksempel illustrerer, hvordan arkitektur og "stedets energi", som en informant kalder det, er med til at understøtte og give signaler til deltagerne om, hvordan stedet kan tages i brug. Da jeg spørger Sebastian, hvorfor de ikke har taget et sted som Godsbanen i brug, som er et offentligt aarhusiansk etableret kultursted, forklarer han:

"Det, vi laver under broen, laver vi, fordi vi føler, at broen indbyder til det. Atmosfæren under de forskellige arrangementer dernede er klart hovedsageligt en effekt af selve broens naturlige karakter. Det er altså ikke et forud tænkt arrangement, som vi så senere skulle finde et sted til. Arrangementet er udsprunget af selve broen og den energi og feeling, der er der.” (Sebastian, interview 20.02.2013).

I citatet fremgår det tydeligt, at måden hvorpå broen tages i brug, ikke er en prædefineret strategi, der, som et udtænkt koncept, kan installeres et hvilken som helst sted i byen. Ifølge Sebastian er ideen udsprunget af stedets fysiske rammer og broens energi, hvilket er betinget af, at de kan sanse potentialet og ændre stedets betydningsstrukturer. Citatet synliggør, at man ikke kan tænke sig til, hvordan et sted som broen kropsligt skal tages i brug. De bryder med broens intenderede funktionalitet, hvilket Sebastian betegner som en nysgerrighed over for stedet. Sebastian nævner "broens naturlige karakter", hvilket jeg, på baggrund af det øvrige empiriske materiale fra broen, tolker som, at de ser bort fra den funktionalitet, som broen er tillagt i et byplanlægningsperspektiv. Informanterne forholder sig udforskende over for stedet og dets potentialer. Dette kan forstås ud fra, hvad den engelske antropolog Tim Ingold betegner som at "sanse sig frem": 
"People do not traverse the surface of the world whose layout is fixed in advance - as represented on the cartographic map. Rather they 'feel their way' through a world that is itself in motion, continually coming into being through the combined action of human and non-human agencies.” (Ingold, I55). ${ }^{\mathrm{I}}$

Ingold anlægger en sanselig optik på brugen af fysiske miljøer og pointerer, at mennesker ikke bevæger sig gennem et allerede etableret stisystem, men sanser sig gennem en verden, som i sig selv er i bevægelse. Der er tale om en måde at være til stede på, som gør det muligt at bryde med etablerede funktionslogikker og bevægelsessystemer. Ingolds citat hjælper med at forstå, hvordan informanterne er indstillet over for byen på en sanselige måde, hvor de skaber forbindelse mellem egen kropslig rytme og de fysiske omgivelser, som giver potentiale til at udforske stedet $\mathrm{i}$ in situ.

Hidtil har jeg analyseret, hvordan informanterne anvender forskellige rumligheder i deres selvorganiserede deltagelsespraksis. Det leder til følgende spørgsmål: Hvordan kan man i et rytmeanalytisk perspektiv forstå, hvordan informanterne skaber forbindelse mellem rytmer og integrerer rytmerne i deres selvorganiserede praksis? I kontrast til institutionaliserede deltagelsesrum, opstår der et praksisparadoks, eftersom informanterne har en hensigt i byen, men hensigten er mere fleksibelt defineret, end det ofte ses i institutionelle rum. Ifølge de informanter jeg har fulgt, handler det snare om oplevelsen af og muligheden for at deltage på måder, de selv definerer og om at skabe betydningsstrukturer ikke bare $i$ men $\mathrm{i}$ forhandling med byen. Det er ikke ensbetydende med, at de selvorganiserede deltagelsesformer er uden struktur. Gennem gentagende analytiske læsninger af det empiriske materiale kommer en organiseringsform til syne i mine analyser. Til trods for at Lefebvre opstiller forskellige rytmetyper (arytmi, eurytmi, polyrytmi og isorytmi), berører han i mindre grad, hvordan rytmiske kompositioner kan forstås som en konkret måde at gå til by-materialitet og organisere sig i byen på. På baggrund af den empiriske analyse tager jeg, i den resterende del af artiklen, rytmeanalysen et metodisk skridt videre ved at kombinere egne observationer fra en musikalsk jamsession. Ved at analysere forholdet mellem selvorganisering og byen nuancerer jeg til slut i artiklen en æstetisk deltagelsespraksis, hvor deltagelsen karakteriseres gennem improvisation.

\section{At jamme og improvisere}

I efteråret 20II observerer jeg flere gange torsdagsarrangementet Jamaften, som finder sted på Det Gule Pakhus i Horsens. Til Jamaften kan alle indtage scenen og spille

"Folk traverserer ikke verdenen, som om dens overflader var optegnet og fikseret på forhånd - som overflader der er repræsenteret på et kort. Mennesker sanser snarere deres vej gennem en verden, der i sig selv er i bevægelse og tager kontinuerligt form i en kombination af menneskelige og ikke-menneskelige handlinger." (Egen oversættelse). 
sammen med folk, de kender og ikke kender. Når informanterne jammer, afventer de nysgerrigt hinandens bevægelser og imødekommer hinanden, når en tone, en takt eller et velkendt riff spilles. De tager ofte udgangspunkt i et velkendt blues-riff, improviserer og opbygger musikken processuelt. Den musikalske komposition, som gradvist ændrer sig, skaber en ny lyd og i Lefebvres terminologi en ny rytmisk gentagelsesform. Det centrale element i en jamsession er, at processen ikke kan konstrueres på forhånd. Selvom processen beror på konkrete færdigheder, teknikker og regler, er det en samstemning af rytmer, der opstår i et sansemæssigt møde. Selvom jamsessionerne foregår indendørs, ser jeg en analytisk sammenhæng mellem den sanselige musikalske interaktion og selvorganiserede by-brug. Med afsæt i en musikalsk analytisk metaforik betragter jeg de tidligere analyserede rumlige forhold som forskellige instrumenter, informanterne anvender i deres selvorganiserede brug af byen.

I værket Noise Orders anskuer David P. Brown arkitektur og byplanlægning gennem fænomenerne improvisation og jazz. En kritik af Browns perspektiv er, at han i overvejende grad berører forholdet mellem improvisation og jazz (Panabaker, Heathcott). I modsætning hertil undersøger jeg med afsæt i musikkens metaforik forholdet mellem selvorganisering, arkitektur og by. Ifølge Brown handler improvisation om en redisciplinering af kroppen, hvor musikeren bryder med faste takter, og musikeren bemestrer nye teknikker, bevægelser og responser (46). Lefebvre nuancerer samspillet af rytmeformerne gennem: arytmi, eurytmi, polyrytmi og isorytmi. Polyrytmiske og eurorytmiske rytmer adskiller sig fra hinanden, ved at en eurorytmik opstår ud fra en rytmisk helhed og et velordnet sammenspil eksempelvis som en symfoni. Polyrytmik betyder, at flere uafhængige rytmer danner en helhed (Rhythmanalysis 6869). At jamme og spille koncert giver begge en harmonisk helhed, men det at jamme differentierer sig fra koncertens symfoniske karakter på grund af rytmernes struktur, sammensætning og den måde, de indskriver sig i tid og rum på. At jamme bygger på erfaringer, men kompositionen sker i øjeblikket ved at sanse og aktivere forskellige musikalske tonearter og rytmer. Når man jammer, skabes rytmen i musikken ud fra gehør og sansning af de andres takter og bevægelser. Jeg relaterer disse handlinger til brugen af byen, hvor det at jamme rækker ud over forholdet mellem musiker og instrumentet.

Ifølge Brown er improvisation ikke blot noget, der sker, når man bevæger sig frem, og er ikke blot forhandlinger mellem det forventede og uventede (Brown xvii). Improvisation handler om at beherske specifikke teknikker: "An individual technique, in improvisation, emerges from the work with the instrument in order to find and develop his or her sound." (45). ${ }^{2}$ Ved at beherske og improvisere med teknikkerne finder og udvikler musikeren sin "egen lyd". I musikinstrumentet ligger teknikker for, hvordan instrumentet skal spilles (46). I forhold til byen, er "instrumentet" ikke defineret på forhånd, og byen har et potentielt større bevægelses- og mulighedsrum, da instrumenterne kan være mangeartede og selvopfundne. Kort sagt handler 
informanternes kropslige redisciplinering om, hvordan de sanser potentialer og gennem improvisation, stemmer rumlige forhold og by-rytmer sammen i en ny organiseringsform. I det følgende relaterer jeg denne tese til empiriske eksempler. Jeg argumenterer for, at der er tale om en rumlig sanselig interaktion, hvor byens matrikelløse rum giver potentiale til, at et improvisatorisk og selvorganisatorisk møde mellem krop, bevægelser, rytmer og arkitektur, kan opstå.

\section{Selvorganisering: At jamme med byens rytmer}

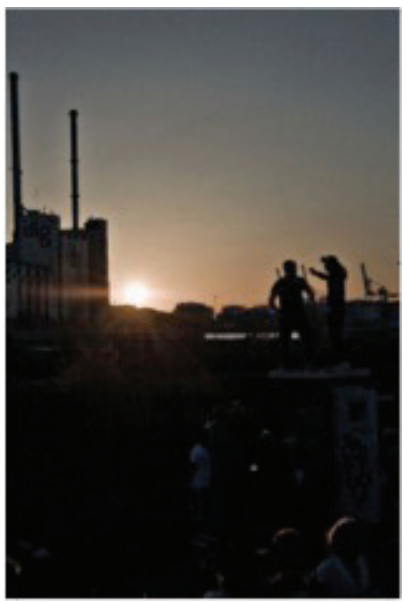

Billede 4

På fotografiet ses silhuetter af mennesker, der danser på jorden og på taget af et skur til en OPP-fest på havnen i Aarhus. Fotografiet viser, hvordan informanterne overskrider måden, hvorpå byen normalt bruges. Dette betragter jeg som et improvisatorisk møde med byen, men informanterne improviserer ikke blot med arkitektur, de opsøger en særlig type steder med bevidsthed om og reference til byens eksisterende normer, regler, autoriteter, rytmer og sociale logikker. Ved at jamme med byens rytmer overskrider de etablerede deltagelseskulturer og forholder sig kropsligt udforskende over for materialiteters funktionalitet. Praksisorganiseringen betegner jeg som en rumlig jamsession.

En større rumlig skala og et rum med mulighed for fri fortolkning kræver en større orkestrering af sted og krop, tid og rum, og hermed praksisorganisering. Ikke alle informanter bemestrer uforudsigeligheden og improvisationen ens, og derfor varierer den selvorganiserede praksis i forhold til omfang, muligheder, deltagere og udtryk. Nogle informanter hænger eksempelvis ud med vennerne, og andre organiserer begivenheder med 300 deltagere. At jamme med byens rytmer skal ikke forstås som en livsstil, hvor informanterne udelukkende bruger byen gennem én praksisform. At jamme med byens rytmer skal forstås som en måde at deltage $\mathrm{i}$ byen på og en organiseringsform, som opstår i et integreret samspil mellem informantens handlinger og byens eksisterende hverdagsliv. 
Brown sondrer mellem lyd og larm, hvormed han argumenterer for, at der inden for musikken eksisterer logikker for, hvad rigtige kompositioner er (I2-I3). Improvisationen består også af at lege med og genanvende det velkendte (Brown, Lefebvre, Writings on Cities). Når informanterne udforsker den rumlige orden ved at bringe rumlige forhold sammen, som normalt ikke er i harmoni, skaber de en ny praksisorganisering. Der er ikke blot tale om en praksis rammesætning i byen eller framing, som antropologen Gregory Bateson betegner det. Den selvorganiserede deltagelsespraksis kan betragtes som en re-framing af byen, da de forhandler byens eksisterende ordner og skaber en ny rytmisk logik. Informanterne redefinerer handlinger fra mere stramme rum til matrikelløse rum, hvilket genererer et potentielt rum for nye deltagelsespraksisser $\mathrm{i}$ byen.

Hvorfor kan informanterne i højere grad jamme og re-frame byens nedlagte bygninger og steder i nattetimerne frem for byens mere præetablerede deltagelsesrum? Forskellen ligger i rytmens struktur. Hvor de linecere rytmer giver mindre plads til subjektiv fortolkning, giver cykliske rytmer derimod mulighed for, at rytmerne kan stemmes sammen i nye kompositioner. At jamme med byens rytmer er en måde at bryde og forhandle med ordenen for forudsigelige begivenheder, steder, tidspunkter og sociale rum, og herigennem vende hverdagslivets rytmik på hovedet. Uforudsigelighed bliver bl.a. et konkret instrument, som informanterne opsøger og aktiverer. Kort sagt laver informanterne deres egne rytmer i byen, som beror på egen organisatoriske, sociale, rum- og tidslige strukturer. På det informanterne betegner for "grå oaser", og jeg analytisk betegner som matrikelløse rum, kan informanterne improvisere, udforske og reorganisere sociale møder og begivenheder selv.

I byen er der noget potentielt modsætningsfyldt, da der er forskellige måder at deltage på, forskellige normer for god by-deltagelse og sociale territoriale grænser. Når formålet med en jamsession er at skabe en ny form for orden og harmoni, hvordan passer byens eksterne rytmer så ind i den nye harmoni? Som tidligere nævnt, afgrænser informanterne deres deltagelsespraksis ved at forholde sig til og tage byens eksterne rytmer i brug, men informanterne skaber ikke en modkultur. De tager aktivt modsætningsfyldte rytmer i brug og skaber deres egen form for harmoni. De indtager eksempelvis bygninger og steder på ulovlig vis, men gør det på en måde, så de ikke oplever et radikalt sammenstød (rytmebrud) med politi eller andre autoriteter. De ser potentialer i sprækker af byen, hvor de tillægger fænomener ny betydning, trafikstøj bliver eksempelvis til god og brugbar lyd, som de afskærmer deres deltagelse gennem. Ved at balancere med en sensitivitet over for byens eksisterende rytmer og eksempelvis ikke gøre noget, der er radikalt ulovligt eller skabe et rytmebrud (arytmi) til andre deltagelsespraksisser i byen, konstruerer informanterne et deltagelsesrum, hvor de kan forhandle eksisterende tids- og rumligheder $i$ byen og improvisere in situ. 


\section{Kroppen i byen - byen i kroppen}

Ved at kombinere antropologisk metodologi med et rytmeanalytisk perspektiv er det $\mathrm{i}$ artiklen fremanalyseret, hvordan den selvorganiserede deltagelsespraksis ikke blot handler om at redefinere materialitet og skabe en legende rammesætning af byen. Selvorganisering handler også om at håndtere og udnytte det konfliktuerende potentiale, der er i byen og dens tidsstrukturer. I artiklen har jeg vist, hvordan de forhandlinger, informanterne foretager i mødet med byen, er af sansemæssig, kropslig og tidslig karakter. Den australske feminist Elisabeth Grosz beskriver forholdet mellem krop og by som cityfied (242). Det betyder, at kroppen er by-lig, og kroppen er sanseligt tunet ind på byen. Grosz understreger, at byen er et produkt af kropslige praksisser, og samtidig er kroppen influeret af byen. Mødet herimellem gør ifølge Grosz, at mennesker reflekterer over deres deltagelsesmuligheder i byen (245), hvilket i høj grad er tilfældet for de informanter, jeg har fulgt. Sammenligneligt med Lefebvre og Thrift anlægger Grosz et dialektisk perspektiv på forholdet mellem krop og by. Med inddragelse af empiriske eksempler har jeg vist, hvordan forbindelser og grænsedragninger til byens rytmer genererer et potentiale for selvorganiserede deltagelsespraksisser. Byen skal ikke forstås som en isoleret historie om stabilitet eller mobilitet, center eller periferi, men derimod som et perspektiv på, hvordan deltagelsesmuligheder opstår i kollision mellem en mangfoldighed af rum- og tidsligheder (Simonsen, Byens 46). Sammenligneligt med den danske social- og kulturgeograf Kirsten Simonsen betragter jeg byens rumligheder og sociale ordener som et vitalt sammentræf (jf. Johnson-Hanks) af forskelligartede rytmer, som både indskriver sig i og afgrænser sig fra andre rumlige praksisser (Edensor and Holloway, Simonsen, Bodies). Styrken ved rytmeanalysen som analytisk metode er dens rytmeanalytiske begrebspar, som gør det muligt at analysere på tværs af steder, rum og praksisser og forstå, hvordan kontrasteringer skaber forbindelser, grænser og overlap mellem deltagelsespraksisser i byen (Lefebvre, Rhythmanalysis 96). Ved at diskutere rytmeanalysen som metode med et konkret empirisk materiale har jeg udviklet begrebet en rumlig jamsession, hvilket er et forsøg på at videreudvikle Lefebvres rytmeanalyse. Den metodiske styrke ved en rumlig jamsession er, at begrebet skaber analytisk grundlag for at nuancere, hvordan rytmer ikke bare spiller sammen, men skaber en ny rumlig organisering og nye betydningsstrukturerer. Såfremt vi skal forsøge at forstå deltagelsespraksisser, som ikke indskriver sig i en specifik kulturinstitution, men beror på en do-it-yourself kultur, kræver det et analytisk blik, der kan indfange sammenspillet mellem kropslige, sanselige og tidslige handlinger. At jamme med byens rytmer er et konkret bud på en aktuel deltagelsesæstetik, som giver unge og voksne mulighed for at udtrykke sig musikalsk og kropsligt ved at improvisere med byens arkitektur, regler og rytmer. Perspektivet understreger nødvendigheden af, at man i byen bevarer matrikelløse rum, da denne type rum giver mennesker mulighed for at lege, udforske og improvisere. 


\section{LITTERATURLISTE}

Amin, Ash and Thrift, Nigel. Cities: Reimagining the Urban. Cambridge: Polity, 2002.

Bateson, Gregory. Steps to an Ecology of Mind. Chicago: University of Chicago Press, 1972.

Bernstein, Basil. "Synlig og Usynlig Pædagogik" Basil Bernstein - Et Udvalg af Hans Artikler om Sprog,

Socialisering og Kontrol. Red. Enggard, J. and Poulsgaard, K. København: Chr. Ejlers’ Forlag, I974.

Brown, Davis. Noise Orders: Jazz, Improvisation, and Architecture. University of Minnesota Press, 1984.

De Certeau, Michel. The Practice of Everyday Life. University of California Press, 1984.

Edensor, Tim. Industrial Ruins: Aesthetics, Materiality and Memory. Ocford: Berg, 2005.

Edensor, Tim and Holloway, Julian. "Rhythmanalysing the Coach Tour: The Ring of Kerry, Ireland."

Transactions of the Institute of British Geographers. 33 (2008): 483-50I.

Franck, Karen, A. and Stevens, Quentin. Loose Space: Possibilities and Diversity in Urban Life. London: Routledge, 2007.

Grosz, Elizabeth. "Bodies-Cities". Sexuality and Space. Red. Beatriz Colomina. New York: Princeton University Press, I992. 24I-253.

Hannerz, Ulf. "Being There... And There... And There!" Ethnograpby 4: 2 (2003): 201.

Heathcott, Joseph. "Bookreview: Noise Orders: Jazz, Improvisation, and Architecture. David Brown.” Journal of Architectural Education 60: 4 (2007): 65-66.

Ingold, Tim. The Perception of the Environment: Essays on Livelihood, Dwelling and Skill. London and New York: Routledge, 2000.

Jenkins, Richard. Social Identitet. Nedslag i sociologien. Vol. I. udgave. Århus: Academica, 2006.

Johnson-Hanks, Jennifer. "On the Limits of Life Stages in Ethnography: Toward a Theory of Vital Conjunctures." American Anthropologist I04: 3 (2002): 865-80.

Lefebvre, Henri. The Production of Space. Malden, Mass: Blackwell, I99I.

Lefebvre, Henri. Rhythmanalysis: Space, Time and Everyday Life. London: Continuum, 2004.

Lefebvre, Henri. Writings on Cities. Oxford: Blackwell Publishers, 1996.

Lefebvre, Henri, and Régulier, Catherine. "Le Projet Rythmanalytique." Communications 4I (1985): I9I-99.

Lefebvre, Henri, and Régulier, Catherine. "Rhythmanalysis of Mediterranean Cities.” Writings on Cities. Red. Lefebvre, Henri. Oxford: Blackwell Publishing, 1996. 228-40.

Marcus, George E. "Ethnography in/of the World System: The Emergence of Multi-Sited Ethnography.” Annual Review of Anthropology 24 (I995): 95-II7.

Merleau-Ponty, Maurice. Kroppens Fanomenologi. Helsingør: Det lille Forlag. 2009.

Panabaker, Ian "Book Review: Brown, David P. Noise Orders: Jazz, Improvisation, and Architecture. Minneapolis: University of Minnesota Press.” Critical Studies in Improvisation 3 I (2007).

Sand, Anne-Lene. Matrikelløse rum - en undersøgelse af selvorganiserede måder at bruge byen på. Ph.dafhandling. Institut for Kulturvidenskaber. Odense: Syddansk Universitet, $20 I 4$.

Simonsen, Kirsten. "Bodies, Sensations, Space and Time: The Contribution from Henri Lefebvre" Geographia Annual 87B I (2005): I-I4.

Simonsen, Kirsten. Byens Mange Ansigter. Roskilde: Roskilde Universitetsforlag, 2005.

Sommer, Robert. Tight Spaces: Hard Architecture and How to Humanize It. Englewood Cliffs, N. J.: Prentice Hall, I974.

Thrift, Nigel. Non-Representational Theory. London and New York: Routledge, 2008. 
